\title{
연구논문
}

\author{
경주국립공원 도심 지역 내 탐방로의 자연도 평가 \\ - 소금강 지구, 화랑 지구, 서악 지구를 대상으로 - \\ 문성주* · 유주한** \\ 동국대학교 대학원 조경학과*, 동국대학교 경주캠퍼스 조경학과*** \\ (2013년 5월 3일 접수, 2013년 7월 24일 승인)
}

\section{Naturalness Assessment of Trails in Urban Area of Gyeongju National Park - Focused on Sogeumgang, Hwarang and Seoak District -}

\author{
Sung-Ju Mun*. Ju-Han You** \\ Department of Landscape Architecture, Graduate School, Dongguk University, Gyeongju, Korea* \\ Department of Landscape Architecture, Dongguk University-Gyeongju, Gyeongju, Korea**
}

(Manuscript received 3 May 2013; accepted 24 July 2013)

\begin{abstract}
The purpose of this study is to offer the raw data for restoration and management of trails by assessing the physical environments, the types of deterioration and the naturalness on trails located in the Sogeumgang, Hwarang and Seoak districts of Gyeongju National Park, Korea. The Sogeumgang was $5.9 \mathrm{~m}, 1.1 \mathrm{~m}$ of the Hwarang and $1.8 \mathrm{~m}$ of the Seoak district in trail width. In the bared width of trail, the Sogeumgang was $3.9 \mathrm{~m}, 0.9 \mathrm{~m}$ of the Hwarang and $1.7 \mathrm{~m}$ of the Seoak district. In the depth of erosion, the Sogeumgang was $37.1 \mathrm{~cm}, 14.2 \mathrm{~cm}$ of the Hwarang and Seoak district. The Sogeumgang was $16.8^{\circ}, 13.1^{\circ}$ of the Hwarang and $12.2^{\circ}$ of the Seoak district in longitudinal slope. In the left and right of transect slope, the Sogeumgang was $18.3^{\circ}$ and $12.6^{\circ}$, $18.0^{\circ}$ and $21.3^{\circ}$ of the Hwarang and $15.3^{\circ}$ and $22.7^{\circ}$ of the Seoak district. In the left, middle and right of soil hardness, the Sogeumgang was $29.9 \mathrm{~mm}, 34.7 \mathrm{~mm}$ and $31.1 \mathrm{~mm}, 27.6 \mathrm{~mm}, 35.0 \mathrm{~mm}$ and $27.2 \mathrm{~mm}$ of the Hwarang and $27.1 \mathrm{~mm}, 30.8 \mathrm{~mm}$ and $28.0 \mathrm{~mm}$ of the Seoak district. The types of deterioration in trails were 10 types of the Sogeumgang, 11 types of the Hwarang and 9 types of the Seoak district. The trail erosion, rock exposure and root exposure were substantially observed in the types of deterioration. In the results of the naturalness assessment, the Hwarang district was a good condition, but the Sogeumgang district was bad. The indicators of the Sogeumgang district were mostly poor.
\end{abstract}

Keywords : deterioration, soil hardness, erosion, exposure

Corresponding author: Ju-Han You, Department of Landscape Architecture, Dongguk University-Gyeongju, Seokjang-dong, Gyeongju, 780-714, Korea Tel: +82-54-770-2230 Fax: +82-54-770-2529 E-mali: youjh@dongguk.ac.kr 


\section{I. 서 론}

우리나라는 경제성장과 더불어 삶의 질이 과거보 다 급속도로 향상되었으며, 이로 인해 여가 및 취미 활동, 건강을 위한 운동, 관광 등이 지속적으로 증가 하고 있는 추세이다. 특히 등산은 운동과 건강의 목 적뿐만 아니라 자연감상, 휴식, 친목도모 등 다양한 목적과 형태로 인기있는 여가활동 중 하나이다. 또한 등산은 특별한 장비나 경비가 들지 않고 자연에서 전 신운동이 가능한 신체활동이며, 스트레스 해소에 도 움을 주기 때문에 많은 사람들이 등산을 선호한다(이 혜숙 등, 2009).

등산은 국립공원과 같은 우리나라의 명산뿐만 아 니라 도시에 있는 소규모 도시림까지 다양한 지역에 서 행해지고 있는데 급증하는 등산인구로 인해 산림 생태계는 심각한 영향을 받고 있다. 특히 등산으로 인해 영향이 집중되는 지역이 등산로이며, 답압으로 발생된 압밀현상과 그로 인한 토양고결화가 발생되 어 강우 시 토양 내부로 물의 유입이 어려워짐에 따 라 등산로의 환경이 불량하게 된다. 또한 등산객들의 이용량 증가로 노폭이 확대됨으로 인해 주변 식생이 교란, 훼손됨에 따라 주변 산림식생에도 심각한 영향 을 초래하고 있는 실정이다.

이러한 등산로는 산림 내 통행을 목적으로 만들어 진 선형의 통로로서 산을 오르기 위해 만든 길을 의 미하며, 국립공원의 경우 어떤 지점과 지점을 걸어서 갈 수 있도록 연결한 길로서 등산, 자연관찰, 자연감 상 등 다양한 목적을 달성하기 위한 길로 정의된다 (문성주, 2013). 따라서 등산로와 탐방로는 유사한 개념으로 산림 내 활동을 지원하기 위한 동선의 의미 를 내포한다.

즉, 탐방로는 산지 내의 선형 통로로서 인간활동에 필요한 시설이나 이용압력이 가중될 경우 생태계에 심각한 악영향을 초래한다. 이러한 측면에서 국립공 원의 탐방로에 대한 연구가 많이 진행되었는데 북한 산국립공원(오구균 등, 1987)은 등산로 파괴에 따른 보수를 위한 기초자료 수집을 목적으로 연구하였는 데 훼손 분석을 가시적 피해등급 3 개 등급만을 사용 하여 구체적인 등급 구분이 미비하였으며, 치악산국
립공원(권태호 등, 1988), 가야산국립공원(권태호 등, 1989) 및 속리산국립공원(권태호 등, 1990)은 등 산로, 야영장 등의 훼손실태를 분석함과 아울러 토 양, 식생 등의 종합적 환경조건을 연구하였으나 노 폭, 나지폭, 침식깊이등 제한적 인자를 조사함으로서 탐방로에 대한 구체적 환경특성 정보가 미비하였을 뿐 만 아니라 객관적 평가기준 제시가 부족하였다. 지리 산국립공원(권태호 등, 1991), 한라산국립공원(오구 균 - 허순호, 1992), 소백산국립공원(권태호 등, 1993), 주왕산국립공원(권태호 등, 1995), 오대산국립공원 (권태호 등, 1996), 설악산국립공원(이준우 등, 1997) 및 월악산국립공원(권태호 등, 2005)은 탐방로의 복 원과 관리를 위해 수행된 것으로 대부분 Frissell (1978)의 5 개 등급을 수정 · 보완하여 6개 등급의 기 준을 활용하였으며, 선적 또는 면적 훼손면적을 산출 하여 적용하였으나 면적 훼손율에만 의존하여 탐방 로의 자연도를 복합적으로 반영하지 못하였다. 덕유 산국립공원(서병수 등, 1994)은 5개 등급과 기초 현 황만을 조사하였으며, 월악산과 치악산국립공원은 전체 노선을 대상으로 조사하여 양적 훼손정보는 확 보되었으나 건전지와 훼손지를 단순하게 토양침식으 로 평가한 문제점을 가지고 있다(정원옥, 2010). 지 리산과 한라산국립공원(김태호, 2011)의 경우 탐방로 의 노면저하, 측면후퇴와 침식, 노면확대와 분기 등 탐방로 훼손요인의 일련의 과정을 체계적으로 분석 하였으나 훼손현상에 대한 객관적 평가기준이 부재 하였다. 설악산과 속리산국립공원(조우, 2012)은 비 개방 탐방로의 관리를 위해 수행되었으나 훼손유형 을 물리적 훼손특성에 기초하여 측정하였을 뿐 이를 기초한 탐방로에 대한 훼손등급 평가는 이루어지지 않았다. 이를 종합해보면, 대부분 국립공원 탐방로 연구는 특정 등급체계 기준만을 적용하였으며, 몇 가 지의 제한된 훼손유형과 그 유형에 따른 구체적 기준 제시가 미비한 것으로 나타나 객관적이고 구체적인 평가등급 제시와 훼손유형 적용이 필요한 시점이다.

경주국립공원은 다른 국립공원에 비해 역사문화자 원이 풍부하고 접근성이 좋아 연중 탐방객들이 증가 하고 있는 추세이며, 특히 본 연구대상지인 소금강 지구, 화랑 지구, 서악 지구는 도시숲의 기능을 하고 
있어 생태적으로 중요한 거점인 동시에 탐방, 등산, 산책 등에 의해 발생되는 인위적 간섭과 교란이 많은 지역이다.

따라서 본 연구는 경주 도심 내에 위치한 경주국립 공원의 소금강 지구, 화랑 지구, 서악 지구에 있는 탐 방로의 훼손실태와 자연도를 조사 및 분석함으로서 탐방로의 유지관리 및 복원을 위한 기초 자료 제공에 목적이 있다.

\section{II. 연구방법}

\section{1. 연구대상지}

경주국립공원은 1968년 12월 31일 우리나라에서 두 번째로 지정된 국립공원으로 국내 유일의 사적형 국립공원이며, 총 면적은 $138.715 \mathrm{~km}^{2}$ 로서 토함산 지 구, 남산 지구, 단석산 지구, 구미산 지구, 대본 지구, 화랑 지구, 소금강 지구, 서악 지구 등 총 8개 지구로 구성되어 있고 국보 11점, 보물 23점, 사적 13 개소, 사적 및 명승 1 개소, 지방문화재 18점 등 총 66 점의 문화재를 보유하고 있다(국립공원관리공단, 2008).

이 중 연구대상지인 소금강 지구는 소금강산(176m) 을 주봉으로 형성된 구릉성 산지로서 전체 면적은 $5.387 \mathrm{~km}^{2}$ 이며, 법정 탐방로는 3 개소, 연장거리는 $3.3 \mathrm{~km}$ 이다. 화랑 지구는 옥녀봉 $(214 \mathrm{~m})$ 과 송화산 $(147 \mathrm{~m})$ 을 주봉으로 형성되어 있으며, 전체 면적은 $3.466 \mathrm{~km}^{2}$ 로서 법정 탐방로는 3 개소, 연장거리는
$4.9 \mathrm{~km}$ 이다. 서악 지구는 선도산 $(380 \mathrm{~m})$ 을 주봉으로 화랑 지구와 인접하여 위치하며, 법정 탐방로는 2 개 소, 연장거리는 $4.0 \mathrm{~km}$ 이고 전체 면적은 $3.830 \mathrm{~km}^{2}$ 이다(문성주, 2013). 이들 3개 지구는 경주시 도심 내 위치하고 있어 지속적인 압력과 간섭이 작용하며, 토 함산 지구, 남산 지구 등과 같이 높은 이용압력에 따 른 복원 및 관리작업이 수행되고 있지 않아 탐방로 복원을 위한 기초자료가 전무하기 때문에 연구를 진 행하였다.

식생개황의 경우 소금강 지구는 소나무군락, 곰솔 군락, 리기다소나무군락 등, 화랑 지구는 소나무군 락, 잣나무군락, 아까시나무군락 등, 서악 지구는 소 나무군락, 리기다소나무군락 등이 분포하고 있다. 경 주시의 기상개황의 경우 평균기온 $13.5^{\circ} \mathrm{C}$, 평균최고 기온 $19.1^{\circ} \mathrm{C}$, 최고극값 $35.3^{\circ} \mathrm{C}$, 평균최저기온 $8.9^{\circ} \mathrm{C}$, 최저극값 $-13.9^{\circ} \mathrm{C}$, 평균강수량 $983.5 \mathrm{~mm}$, 평균상대 습도 $60.3 \%$, 평균풍속 $8.2 \mathrm{~m} / \mathrm{s}$ 이며, 대륙성 기후로 한서차가 크다(경주시, 2012).

\section{2. 조사 및 분석방법}

\section{1) 현장조사}

현장조사는 2011년 3월과 4월에 1차 조사를 실시 하여 탐방로 주변 환경 및 여건, 개략적 지형, 탐방로 형태 등의 기초 정보를 수집하였으며, 이를 바탕으로 2011년 7월부터 9월까지 탐방로의 물리적 환경특성,

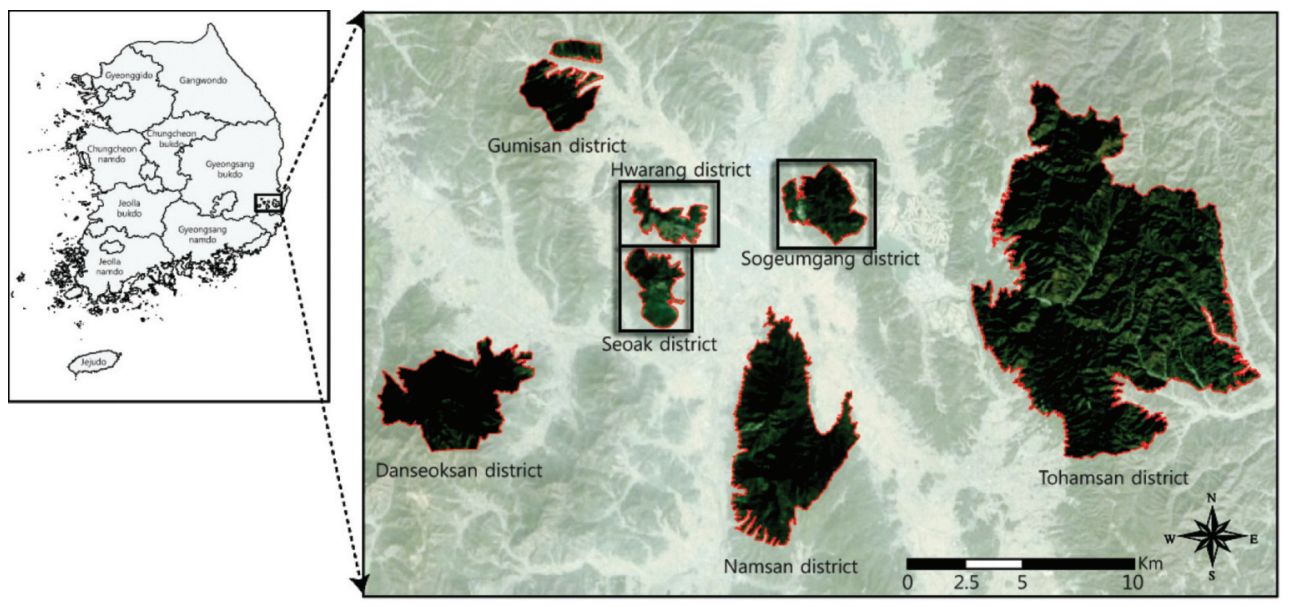

Figure 1. The survey sites in Gyeongju National Park 


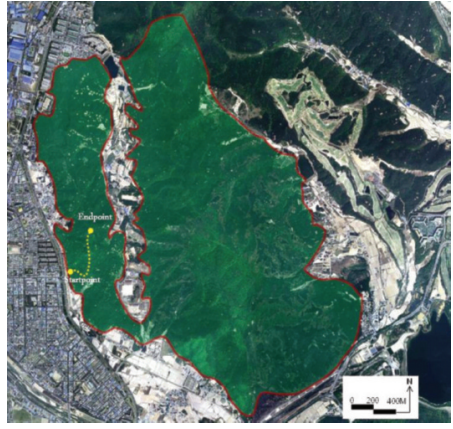

Sogeumgang district

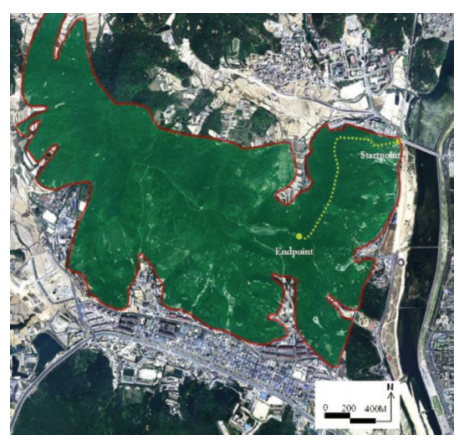

Hwarang district

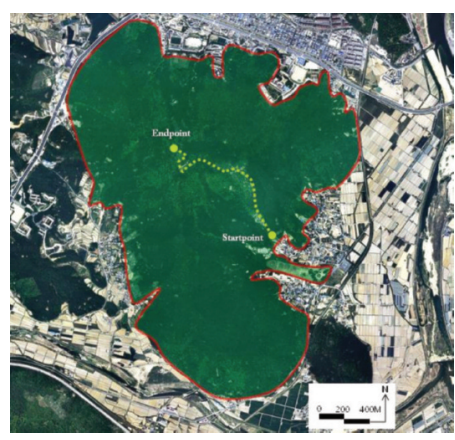

Seoak district

Figure 2. The survey routes of this study

훼손 유형, 자연도 평가를 수행하였다. 탐방로의 위 치, 노선형태 등은 국토지리정보원 발행 1:5,000 수 치지형도, 경주국립공원 안내지도, 위성영상 등을 토 대로 조사를 진행하였다.

노선길이의 경우 소금강 지구 $0.65 \mathrm{~km}$, 화랑 지구 $1.3 \mathrm{~km}$, 서악 지구 $1.6 \mathrm{~km}$ 로 선정하였으며, 측점수는 소금강 지구 12 개, 화랑 지구 18 개, 서악 지구 23 개를 설치하여 조사하였다. 상기지구 및 탐방로는 탐방객 수를 측정할 수 있는 게이트가 설치되어 있지 않아 정 확한 탐방객수는 현재 집계되지 않았으므로 탐방객 수에 의한 노선선정은 본 연구에서 적용할 수 없었다. 따라서 본 연구에서의 노선선정은 경주국립공원사무 소의 탐방로 실무진에 대한 자문결과, 접근성이 가장 용이하여 탐방객수가 많고 각 지구를 가장 대표할 수 있는 구간이며, 경주시에서부터 국립공원 관리 이관 후 복원이 시급한 구간이라는 점에서 기인하여 구간 선정을 수행하였다. 특히 서악 지구는 선정된 탐방로 이외에는 산불 피해로 인해 생태복원으로 폐쇄된 상 태이기 때문에 1 개 노선을 선정하였으며, 소금강 지 구도 동측 지구가 산불로 인해 폐쇄 및 복원구간이 많 이 있다. 그리고 화랑 지구의 노선은 주 탐방로이며, 기타 탐방로는 부 탐방로 또는 임도 기능을 가지고 있 어 연구 시 평가결과의 왜곡현상이 발생될 가능성이 있어 상기 탐방로를 선정하였다(Figure 2).

조사구간은 소금강 지구의 경우 굴불사지 소금강 산, 화랑지구는 동대교 송화산, 서악 지구는 무열왕 릉 선도산이며, 이 지역들은 지구별로 가장 대표적 인 탐방구간이다.
탐방로의 물리적 환경은 탐방로의 기초 속성정보 로서 많은 환경항목이 있으나 탐방로의 환경특성을 대표할 수 있는 노선길이, 노폭, 나지폭, 침식깊이, 종단구배, 횡단구배, 토양경도에 대해 조사하였으며, 이들 항목은 국립공원 탐방로 관련 연구에서 보편적 으로 사용된 항목을 추출하였다(권태호 등, 1990; 권 태호 등, 1991; 오구균 - 허순호, 1992; 권태호 등, 1993; 산림청, 2004; 권태호 등, 2005 ; 국립공원관 리공단, 2009; 정원옥, 2010). 노선길이는 조사 시점 과 종점까지의 거리를 측정하였으며, 노선 상에서 탐 방로 평가 측점을 $50 \sim 100 \mathrm{~m}$ 간격으로 선정하였고 GPS(GARMIN, GPSmap60CS, USA)를 사용하였 다. 노폭은 탐방로의 좌측단과 우측단의 횡단길이를 측정하였으며, 나지폭은 노폭에서 식생이 훼손되어 나지화된 지역을 조사하였고 방법은 노폭과 동일하 다. 침식깊이는 노선 상에서 세굴현상이 발생된 지점 에 대해 측정한 것으로 알루미늄 함척(SB, ST-55M, Korea)을 수평으로 설치한 후 줄자(Komelon, Phantom Fiber, Korea)를 수직으로 내려 침식깊이를 조사하였다.

종단구배는 노선 상에 경사계(BRUNTON, 15TDCL, $\mathrm{USA}$ )를 설치하여 측정하였으며, 횡단구배는 노선의 좌측단과 우측단의 구배를 조사하였다. 토양경도는 노 선 상 좌측, 중간, 우측의 3 부분으로 구분한 후 토양경 도계(TAKEMURA, SHM-1, Japan)를 이용하여 조사 하였다.

\section{2) 분석방법}

훼손 유형은 기존 관련 문헌(산림청, 2004 ; 국립 


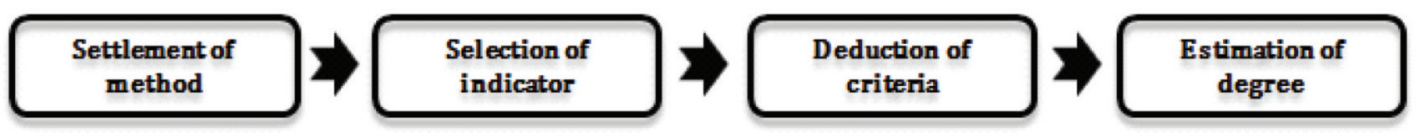

Figure 3. The process of assessing the naturalness in trails

공원관리공단, 2009)을 통해 17개 유형을 선정하여 연구지역 내의 유형구분을 실시하였다. 산림청과 국 립공원관리공단에서 제시한 공통 훼손유형은 노면침 식의 경우 노면침식형, 노면세굴형, 경계침식형, 암 석풍화형, 노폭확대는 샛길형, 노폭확대형, 암반노출 형, 수목뿌리노출형, 노면주변훼손은 노면주면 훼손 형, 노면보행불편은 노면배수불량형, 노폭협소형, 자 갈불편형, 급경사형이며, 산림청에서만 제시된 유형 은 노면보행불편의 경우 계단높이불편형이다. 그리 고 국립공원관리공단에서만 제시된 유형은 붕괴형, 땅밀림형, 유동형 등과 같은 산사태 관련 유형이다.

이들 조합한 결과, 훼손 유형의 세부적 분류는 노면 침식의 경우 노면침식형, 노면세굴형, 경계침식형, 암 석풍화형 등 4 개 유형, 노폭확대는 샛길형, 노폭확대 형, 암반노출형, 수목뿌리노출형 등 4개 유형, 노면주 변훼손은 노면주변훼손형 등 1 개 유형, 노면보행불편 은 계단높이 불편형, 노면배수 불량형, 노면폭 협소 형, 구슬자갈 불편형, 급경사형 등 5 개 유형, 산사태 는 붕괴형 산사태, 땅밀림형 산사태, 유동형 산사태 등 3 개 유형 등이다. 이는 본 지역이 국립공원인 동시 에 산지인 점을 감안하여 산림청과 국립공원관리공단 에서 제시한 훼손유형을 조합하여 사용하였다.

자연도 평가는 Figure 3 과 같은 과정을 통해 진행되
었다. 첫 번째, 평가방법 설정은 관련 평가방법의 체계 및 기준(Frisell, 1978; Leung and Marion, 2009b; 권태호 등, 1991; 국립공원 관리공단, 2009)에 대해 검 토하여 본 연구와 부합되는 방법을 설정하였다.

두 번째, 평가지표의 선정은 탐방로 훼손 및 이용영 향에 관련된 연구(오구균 등, 1987; 권태호 등, 1988; 권태호 등, 1989; 권태호 등, 1990; 권태호 등, 1991; 권태호 등, 1993; 권태호 등, 1994; 권태호 등, 1995; 권태호 등, 1996; 이준우 등, 1997; 안현철 등, 1998; 권태호 · 이준우, 2003; Lynn and Brown, 2003; 권 태호 등, 2005; 오경원 - 박종민, 2005; 최충호 등, 2005; 정원옥 · 권헌교, 2008; Leung and Marion, 2009a; 박은희 등, 2010; 정원옥, 2010; 정원옥 - 정 평희, 2010; 박인환 등, 2010; 강태호 등, 2011; 김태 호, 2011; 정원옥 등, 2011; 김태호, 2012; 조우, 2012; Moore et al., 2012)에서 사용된 평가지표를 추출하 여 상위 5 개 지표인 노면침식, 노폭확대, 수목뿌리노 출, 샛길, 암반노출을 선정하였다(Table 1). 또한 노 면주변 훼손의 경우 출현빈도는 낮으나 평가지표로 선정하였는데 이는 다른 국립공원과 달리 경주국립공 원의 도심 내 지구는 탐방로 주변으로 텃밭, 사유지, 과수원, 묘지, 불법 시설물 등이 많이 존재하기 때문 에 본 연구에서 적용하기 위해 선정하였다.

Table 1. The selection of indicators by frequency

\begin{tabular}{c|c|c|c|c|c|c|c}
\hline \hline No. & Indicator & Frequency & ratio(\%) & No. & Indicator & Frequency & ratio(\%) \\
\hline 1 & Trail erosion & 28 & 100.0 & 10 & Discomfort of stair height & 2 & 7.1 \\
\hline 2 & Trail expansion & 25 & 89.3 & 11 & Trail narrowness & 2 & 7.1 \\
\hline 3 & Root exposure & 25 & 89.3 & 12 & Discomfort of gravel & 2 & 7.1 \\
\hline 4 & Divergence & 23 & 82.1 & 13 & Steep slope & 2 & 7.1 \\
\hline 5 & Rock exposure & 23 & 82.1 & 14 & Deterioration of surrounding & 1 & 3.6 \\
\hline 6 & Border erosion & 11 & 39.3 & 15 & Others & 1 & 3.6 \\
\hline 7 & Poor trail drainage & 8 & 28.6 & 16 & Collapse & - & - \\
\hline 8 & Trail scouring & 4 & 14.3 & 17 & Land creeping & - & - \\
\hline 9 & Rock weathering & 2 & 7.1 & 18 & Land flux & - & - \\
\hline \hline
\end{tabular}

Source: Mun(2013) 
Table 2. The assessment criteria of naturalness

\begin{tabular}{|c|c|c|c|}
\hline Indicator & Content & Score & Criteria \\
\hline \multirow{5}{*}{ Trail erosion } & \multirow{5}{*}{$\begin{array}{l}\text { Intensity and frequency of trail } \\
\text { erosion }\end{array}$} & 1 & The Surface-covers remain in trail. \\
\hline & & 2 & The partially bared grounds exist in trail. \\
\hline & & 3 & The depth of erosion is below $10 \mathrm{~cm}$. \\
\hline & & 4 & The depth of erosion is below $20 \mathrm{~cm}$. \\
\hline & & 5 & The depth of erosion is over $20 \mathrm{~cm}$. \\
\hline \multirow{5}{*}{ Trail expansion } & \multirow{5}{*}{$\begin{array}{l}\text { Bared width and deteriorated } \\
\text { level }\end{array}$} & 1 & The bared width is below $1.2 \mathrm{~m}$. \\
\hline & & 2 & The bared width is from $1.2 \mathrm{~m}$ to $1.5 \mathrm{~m}$. \\
\hline & & 3 & The bared width is from $1.5 \mathrm{~m}$ to $1.8 \mathrm{~m}$. \\
\hline & & 4 & The bared width is from $1.8 \mathrm{~m}$ to $2.1 \mathrm{~m}$. \\
\hline & & 5 & The bared width is over $2.1 \mathrm{~m}$. \\
\hline \multirow{5}{*}{ Root exposure } & \multirow{5}{*}{$\begin{array}{l}\text { Intensity and frequency of root } \\
\text { exposure }\end{array}$} & 1 & The roots are not exposed in trail. \\
\hline & & 2 & The root exposure in below $5 \%$ \\
\hline & & 3 & The root exposure in below $10 \%$ \\
\hline & & 4 & The root exposure in below $20 \%$ \\
\hline & & 5 & The root exposure in over 5\% \\
\hline \multirow{5}{*}{ Trail divergence } & \multirow{5}{*}{$\begin{array}{l}\text { Deteriorated level by trail } \\
\text { divergence }\end{array}$} & 1 & Nothingness \\
\hline & & 2 & The trail divergence is 1 time. (The bared width is below $2.1 \mathrm{~m}$.) \\
\hline & & 3 & The trail divergence is 1 time. (The bared width is over $2.1 \mathrm{~m}$.) \\
\hline & & 4 & The trail divergence is 2 time. \\
\hline & & 5 & The trail dievergece is over 2 time. \\
\hline \multirow{5}{*}{ Rock exposure } & \multirow{5}{*}{$\begin{array}{c}\text { Intensity and frequency of rock } \\
\text { exposure }\end{array}$} & 1 & The rocks are not exposed in trail. \\
\hline & & 2 & The rock exposure in below 5\% \\
\hline & & 3 & The rock exposure in below $10 \%$ \\
\hline & & 4 & The rock exposure in below $20 \%$ \\
\hline & & 5 & The rock exposure in over $20 \%$ \\
\hline \multirow{5}{*}{$\begin{array}{l}\text { Deterioration of } \\
\text { surrounding }\end{array}$} & \multirow{5}{*}{ Deteriorated level around trail } & 1 & The deteriorated level is below $100 \mathrm{~m}^{2} / \mathrm{km}$. \\
\hline & & 2 & The deteriorated level is from $100 \mathrm{~m}^{2} / \mathrm{km}$ to $400 \mathrm{~m}^{2} / \mathrm{km}$. \\
\hline & & 3 & The deteriorated level is from $400 \mathrm{~m}^{2} / \mathrm{km}$ to $700 \mathrm{~m}^{2} / \mathrm{km}$. \\
\hline & & 4 & The deteriorated level is from $700 \mathrm{~m}^{2} / \mathrm{km}$ to $1,000 \mathrm{~m}^{2} / \mathrm{km}$. \\
\hline & & 5 & The deteriorated level is over $1,000 \mathrm{~m}^{2} / \mathrm{km}$ \\
\hline
\end{tabular}

Source: Mun(2013)

세 번째, 선정된 평가지표를 탐방로 자연도 평가에 적용하기 위해 평가방법 및 평가지표와 관련된 문헌 과 경주국립공원 탐방로 관련 실무진인 문화자원과 3 명, 탐방시설과 4 명의 자문을 토대로 기준을 도출 하였으며, 평가지표별로 자연성 정도에 따라 1 점에서 5점의 점수를 부여하였다(Table 2). 즉, 1점은 건전 한 상태이며, 5 점은 불량한 상태를 의미한다.

노면침식은 과도한 이용압력에 의해 난투수층이 발생되면서 탐방로의 표면에 토양이 강우에 의해 유 실되는 현상으로 평가기준은 노면에 지피물이 남아
있는 지역은 1 점, 나지화가 부분적으로 진행된 지역 은 2점, 노면침식이 $10 \mathrm{~cm}$ 이하 지역은 3 점, 침식이 $20 \mathrm{~cm}$ 이하 지역은 4 점, 침식이 $20 \mathrm{~cm}$ 초과 지역은 5 점으로 침식에 의한 훼손진행과정과 정도를 고려하 여 평가하였다(Frissell, 1978; 권태호 등 1991; Leung and Marion, 2000a). 노폭확대에 있어 노폭 은 탐방로의 상태를 표현하고 탐방로 주변의 입지적 특성, 이용행태 및 이용량 등의 영향을 반영하는 지 표이다(최충호 등, 2005).

등급 구분의 경우 나지폭이 $1.2 \mathrm{~m}$ 이하는 1 점, 나 
Table 3. The naturalness degree of trails

\begin{tabular}{c|c|c|c|c|c}
\hline \hline Degree & I & II & III & V & V \\
\hline Range & $1.0 \leqq \mathrm{I} \leqq 1.8$ & $1.8<\mathrm{II} \leqq 2.6$ & $2.6<\mathrm{III} \leqq 3.4$ & $3.4<\mathrm{V} \leqq 4.2$ & $4.2<\mathrm{V} \leqq 5.0$ \\
\hline Condition & Good & a little good & Medium & a little poor & Poor \\
\hline Plan & Conservation & a little management & Management & a little restoration & Restoration \\
\hline \hline
\end{tabular}

Source: $\operatorname{Mun}(2013)$

지폭이 $1.2 \mathrm{~m}$ 초과 $1.5 \mathrm{~m}$ 이하는 2 점, 나지폭 $1.5 \mathrm{~m}$ 초 과 $1.8 \mathrm{~m}$ 이하는 3 점, 나지폭 $1.8 \mathrm{~m}$ 초과 $2.1 \mathrm{~m}$ 이하 는 4점, 나지폭 $2.1 \mathrm{~m}$ 초과는 5 점을 부여하였다. 적 정 노폭의 선정은 국립공원관리공단(2011)이 제시한 기준 즉, 탐방객이 많을 경우 $2.0 \mathrm{~m}$, 중간일 경우 $1.5 \mathrm{~m}$, 적을 경우 $1.2 \mathrm{~m}$ 를 기준으로 적용하였으며, 평 기기준은 Leung and Marion(2000b)와 국립공원관 리공단(2009)을 참고하였다.

수목뿌리노출은 탐방로 주변의 수목뿌리가 노출되 면서 수목의 생육을 불량하게 함과 아울러 통행에 악 영향을 미쳐 다른 훼손유형을 발생을 초래한다. 이러 한 수목뿌리노출은 탐방로 훼손을 평가하는 척도로 사용되는데(김세천 · 박종민, 1998; 권태호 등 2005) 지피물이 남아 있어 수목뿌리가 노출되지 않은 지역 은 1점, 뿌리가 $5 \%$ 정도로 극히 일부만 노출된 지역 은 2점, 뿌리노출이 $10 \%$ 이하 지역은 3 점, $20 \%$ 이하 지역은 4점, $20 \%$ 초과 지역은 5 점을 부여하였고 Frissell(1978), 권태호 등(1991) 및 장은재 등 (2007) 의 문헌을 바탕으로 수정 - 보완하여 적용하였다. 샛 길은 노면침식, 세굴 및 탐방로의 배수불량으로 발생 된 통행 방해요인을 피하기 위해 새로운 동선이 발생 된 형태를 의미하는 것으로샛길이 없는 지역은 1점, 샛길이 1 회 발생되었고 나지폭 합이 $2.1 \mathrm{~m}$ 이하인 지 역은 2 점, 샛길이 1 회 발생되었고 나지폭 합이 $2.1 \mathrm{~m}$ 초과인 지역은 3 점, 샛길이 2 회 발생된 지역은 4점, 샛길이 2 회 초과 발생한 지역은 5 점을 부여하였다. 여기서 $2.1 \mathrm{~m}$ 는 앞서 언급한 노폭의 최대폭을 적용하 였으며, 산림청(2004) 및 국립공원관리공단(2009; 2011)의 자료 근거를 토대로 작성하였다.

암반노출은 암석지반의 탐방로에서 과도한 이용압 력이 발생되어 암반을 얇게 피복하고 있는 토양이 유 실되면서 암반이 노출되는 현상으로 암반이 노출되
지 않은 지역은 1점, 암반이 $5 \%$ 이하 노출된 지역은 2점, 노출이 $10 \%$ 이하 지역은 3 점, $20 \%$ 이하 지역은 4점, $20 \%$ 초과 지역은 5점이며, Frisell(1978), 권태 호 등(1991), 권태호 등(1995), 국립공원관리공단 (2009) 및 정원옥(2010)의 연구결과를 기초로 수 정 - 보완하여 사용하였다.

노면주변 훼손은 면적 훼손이 발생되는 공간으로 주로 시설물, 묘지, 나지 등에 의해 훼손된 지역이다. 등급 구분은 탐방로 주변 훼손이 $100 \mathrm{~m}^{2} / \mathrm{km}$ 이하이 면 1점, $100 \sim 400 \mathrm{~m}^{2} / \mathrm{km}$ 이면 2점, $400 ~ 700 \mathrm{~m}^{2} / \mathrm{km}$ 이면 3점, $700 ~ 1,000 \mathrm{~m}^{2} / \mathrm{km}$ 이면 4점, $1,000 \mathrm{~m}^{2} / \mathrm{km}$ 초과이면 5점을 부여하였으며, 본 등급은 국립공원 관리공단에서만 사용되는 지표이기 때문에 국립공원 관리공단(2009; 2011)의 문헌을 근거로 사용하였다.

네 번째, 자연도 평가등급 산정은 평가지표의 점수 를 산출하는 과정으로 평가기준에 의해 획득된 점수 를 지표별로 합산하여 산술평균하였다. 자연도 평가 등급의 범위는 I V등급까지 5 단계로 구분하였으며, 등급별로 0.8 점의 등간격이 되도록 하였는데 이는 최 소값과 최대값의 평균 내 평가지표의 점수 분포를 해 당 범위 내에서 측정할 수 있도록 하기 위함이다. 평 가점수의 범위는 1.0 이상 1.8 이하일 경우 I등급, 1.8 초과 2.6 이하면 II등급, 2.6 초과 3.4 이하면 III등 급, 3.4 초과 4.2 이하면 V등급, 4.2 초과 5.0 이하 면 V등급으로 산정하였다(Table 3).

\section{III. 결과 및 고찰}

\section{1. 물리적 환경}

지구별 탐방로의 물리적 환경을 분석한 결과, 평균 노폭의 경우 소금강 지구 $5.9 \mathrm{~m}$, 화랑 지구 $1.1 \mathrm{~m}$, 서 악 지구 $1.8 \mathrm{~m}$ 이며, 평균나지폭은 소금강 지구 $3.9 \mathrm{~m}$, 
화랑 지구 $0.9 \mathrm{~m}$, 서악 지구 $1.7 \mathrm{~m}$ 로 나타났다(Table 4). 평균침식깊이는 소금강 지구 $37.1 \mathrm{~cm}$, 화랑 지구 및 서악 지구 $14.2 \mathrm{~cm}$ 이며, 종단구배는 소금강 지구 $16.8^{\circ}$, 화랑 지구 $13.1^{\circ}$, 서악 지구 $12.2^{\circ}$ 로 조사되었다.

횡단구배의 좌측과 우측을 살펴보면, 소금강 지구 $18.3^{\circ}, 12.6^{\circ}$, 화랑 지구 $18.0^{\circ}, 21.3^{\circ}$, 서악 지구 $15.3^{\circ}$, $22.7^{\circ}$ 로 나타났다. 토양경도의 좌측, 중간, 우측을 살 펴보면, 소금강 지구 $29.9 \mathrm{~mm}, 34.7 \mathrm{~mm}, 31.1 \mathrm{~mm}$, 화랑 지구 $27.6 \mathrm{~mm}, 35.0 \mathrm{~mm}, 27.2 \mathrm{~mm}$, 서악 지구 $27.1 \mathrm{~mm}, 30.8 \mathrm{~mm}, 28.0 \mathrm{~mm}$ 로 조사되었다.

평균노폭, 평균나지폭, 평균침식깊이, 종단구배는 소금강 지구가 가장 높은 값을 나타내었다. 횡단구배 에 있어 좌측은 소금강 지구, 우측은 서악 지구가 급 했으며, 토양경도 중 좌측과 우측은 소금강 지구, 중 간은 화랑 지구가 높게 조사되었다. 구배가 급하다는 것은 경사가 급하다고 할 수 있는데 이러한 지역은 사면침식이 발생되고 사면붕괴 발생위험성이 크다고 할 수 있다(정원옥, 2010). 또한 토양침식은 토양의 물리적 특성뿐만 아니라 지형적 조건에 의해 발생되 고 지역의 환경문제에 영향을 준다(박인환 등, 2006). 따라서 이러한 지역은 사면붕괴를 막을 수 있 는 재해방지 대책이 수립되어야 하며, 아울러 주변 생태계와 부합되는 자연친화적인 공법이 적용되어야 할 것으로 생각된다.

종단구배가 급한 소금강 지구는 침식깊이가 가장 깊었는데 구배가 급할수록 강우 시 유속이 급해져 완 만한 지역보다 침식이 더 발생된다 할 수 있어 구배 와 침식은 상호 관련성이 있다. 이는 국립공원의 탐 방로 조사 시 종단구배와 침식깊이가 유의한 관계를 가진다(조우, 2012)고 하였는데 본 연구와 유사한 양 상을 나타내어 경사와 침식은 상호 연관성이 있다고
할 수 있다.

토양경도의 경우도 소금강 지구에서 대체적으로 높게 조사되었는데 토양경도가 높다는 것은 노면 자 체가 답압에 의해 다져져 공극이 거의 없고 난투수층 이 발생됨과 아울러 식생의 발생이 어려운 상태를 의 미한다. 또한 탐방로의 토양경도에서 좌측과 우측보 다는 중간이 경도가 높게 조사되었는데 이는 탐방객 들의 통행이 중간에 집중되어 나타난 결과로서 한라 산의 경우에서도 중간이 높게 나타난 것(김태호, 2003)으로 미루어볼 때 탐방로 중간이 답압에 가장 취약한 것으로 판단된다. 따라서 탐방로의 토양환경 개선을 위해서는 통행량 조절과 함께 탐방로 상에 우 드칩 등과 같은 천연피복재료를 활용하는 방안이 필 요할 것이며, 특히 우드칩은 답압과 나지화를 방지할 수 있다(조현길 등, 2011).

\section{2. 훼손 유형}

탐방로의 훼손유형은 소금강 지구 10 개 유형, 화랑 지구 11 개 유형, 서악 지구 9 개 유형으로 분석되었다 (Table 5). 가장 많이 출현한 유형의 경우 소금강 지 구는 노면침식형 $(\mathrm{A})$, 샛길형 $(\mathrm{E})$, 수목뿌리노출형 $(\mathrm{H})$ 이 10 회, 화랑 지구는 수목뿌리노출형 $(\mathrm{H})$ 이 14 회, 서 악 지구는 노면침식형 $(\mathrm{A})$ 이 18회로 나타났다. 3 개 지 구에서 공통적으로 나타난 유형은 노면침식형 $(\mathrm{A})$, 노 면세굴형 $(\mathrm{B})$, 경계침식형 $(\mathrm{C})$, 암반노출형 $(\mathrm{G})$, 수목뿌 리노출형 $(\mathrm{H})$, 노면주변훼손형(I)으로 확인되었으며, 이 중 노면침식형, 암반노출형, 수목뿌리노출형이 많 이 관찰되었다.

이들은 토양침식 또는 유실에 관계되는 유형으로 강우 시 발생되는 지표수가 노면을 유하하면서 토양 이 유실 또는 침식됨과 함께 암반 또는 수목뿌리가 노 출되는 형태이다. 또한 과도한 이용에 의해서도 발생

Table 4. The characteristics of physical environment of trails by districts

\begin{tabular}{|c|c|c|c|c|c|c|c|c|c|}
\hline \multirow{2}{*}{ District } & \multirow{2}{*}{$\begin{array}{l}\text { Trail width } \\
\text { (m) }\end{array}$} & \multirow{2}{*}{$\begin{array}{l}\text { Bared width } \\
\text { (m) }\end{array}$} & \multirow{2}{*}{$\begin{array}{l}\text { Depth of erosion } \\
(\mathrm{cm})\end{array}$} & \multirow{2}{*}{$\begin{array}{l}\text { Longitudinal slope } \\
\qquad\left(^{\circ}\right)\end{array}$} & \multicolumn{2}{|c|}{ Transect slope $\left({ }^{\circ}\right)$} & \multicolumn{3}{|c|}{ Soil hardness(mm) } \\
\hline & & & & & Left & Right & Left & Middle & Right \\
\hline Sogeumgang & 5.9 & 3.9 & 37.1 & 16.8 & 18.3 & 12.6 & 29.9 & 34.7 & 31.1 \\
\hline Hwarang & 1.1 & 0.9 & 14.2 & 13.1 & 18.0 & 21.3 & 27.6 & 35.0 & 27.2 \\
\hline Seoak & 1.8 & 1.7 & 14.2 & 12.2 & 15.3 & 22.7 & 27.1 & 30.8 & 28.0 \\
\hline Mean & 2.9 & 2.2 & 21.8 & 14.0 & 17.2 & 18.9 & 28.2 & 33.5 & 28.8 \\
\hline
\end{tabular}


Table 5. The types of deterioration in trails by districts

\begin{tabular}{c|c|c|c|c|c|c|c|c|c|c|c|c|c|c|c|c|c}
\hline \hline District & A & B & C & D & E & F & G & H & I & J & K & L & M & N & O & P & Q \\
\hline Sogeumgang & 10 & 8 & 4 & - & 10 & 5 & 9 & 10 & 4 & - & - & - & - & 4 & 1 & - & - \\
\hline Hwarang & 13 & 1 & 1 & - & 7 & 4 & 8 & 14 & 3 & - & 2 & - & 1 & 1 & - & - & - \\
\hline Seoak & 18 & 4 & 5 & - & - & - & 14 & 5 & 4 & - & 5 & - & 15 & - & 4 & - & - \\
\hline Mean & 13.7 & 4.3 & 3.3 & - & 5.7 & 3.0 & 10.3 & 9.7 & 3.7 & - & 2.3 & - & 5.3 & 1.7 & 1.7 & - & - \\
\hline \hline
\end{tabular}

A: Trail erosion, B: Trail scouring, C: Border erosion, D: Rock weathering, E: Divergence, F: Trail expansion, G: Rock exposure, H: Root exposure, I: Deterioration of surrounding, J: Discomfort of stair height, K: Poor trail drainage, L: Trail narrowness, M: Discomfort of gravel, N: Steep slope, O: Collapse, P: land creeping, Q: land flux

되는데 박인환 등(2010)은 대구 앞산에서도 이용에 따른 침식, 암반 및 수목뿌리 노출을 언급하였다. 또 한 월악산국립공원의 경우 수목뿌리노출, 암반노출, 침식 등이 경사와 관련되었다고 제시하였다(권태호 등, 2005). 따라서 상기 훼손유형은 경사에 의한 발생 되는 지표수 유하로 인해 발생되며, 상태가 불량해진 지역에 탐방객들의 이용이 과도하게 발생된 것으로 자연적, 인위적 요인이 함께 작용한다고 할 수 있다.

특히 수목의 뿌리노출은 토양침식을 가속화시키고 침식깊이에 영향을 받는다(임원현 등, 2009). 특히 수목뿌리는 토양입자와 결합하여 토양층을 지지하고 사면 붕괴를 억제하는 효과가 있는데 토양침식으로 인한 뿌리노출현상이 발생하는 것은 토양지지력이 약화되었다는 증거가 될 수 있다. 따라서 뿌리노출지 역에는 복토, 뿌리보호공을 적용하여 침식을 억제할 수 있는 관리대책이 필요할 것이다.

\section{3. 자연도 평가}

지구별 탐방로의 자연도 평가결과는 Table 6 과 같 이 요약되었다. 소금강 지구의 경우 노면침식 $\mathrm{V}$ 등급, 샛길 III등급, 노폭확대 및 암반노출 V등급, 수목뿌 리노출 V등급, 노면주변훼손 III등급이며, 화랑 지구 는 노면침식 $\mathrm{V}$ 등급, 샛길 및 노폭확대 I등급, 암반노 출 II등급, 수목뿌리노출 V등급, 노면주변훼손 III등 급으로 나타났다. 서악 지구는 노면침식 $\mathrm{V}$ 등급, 샛길 I등급, 노폭확대 III등급, 암반노출 V등급, 수목뿌리 노출 I등급, 노면주변훼손 III등급으로 확인되었다. 평가지표별로 살펴보면, 노면침식, 샛길, 노폭확대, 수목뿌리노출은 소금강 지구에서 가장 불량하였으 며, 암반노출은 소금강 지구와 서악지구에서 가장 불
량한 것으로 조사되어 대부분 소금강 지구의 탐방로 상태가 불량하였다. 지구별 탐방로의 자연도 평가의 경우 소금강 지구 $\mathrm{V}$ 등급, 화랑 지구 II등급, 서악 지 구 III등급으로 나타났으며, 3 개 지구의 평균 등급은 III등급으로 분석되어 평가지표와 함께 전체 구간도 소금강 지구가 가장 불량하였다.

경주국립공원 8 개 지구 중 소금강 지구, 화랑 지 구, 서악 지구는 다른 지구와 달리 문화재 관람보다 는 경주시민들의 건강 증진목적으로 이용되는 지역 으로(국립공원관리공단, 2008) 대체적으로 가벼운 운동 및 산책이 행해지는 근린공원 기능을 가지고 있 다. 근린공원은 유치거리가 $1 \mathrm{~km}$ 이하이고 도보권에 거주하는 자가 주 이용자가 된다(안봉원 등, 1991). 이러한 측면에서 각 지구별 이용권을 살펴보면, 반경 $1 \mathrm{~km}$ 내에는 소금강 지구가 황성동, 동천동, 용강동, 화랑지구는 성건동, 현곡면, 서악 지구는 선도동이 포함되며, 인구의 경우 소금강 지구가 73,137 명, 화 랑 지구 34,981 명, 서악 지구 14,809 명으로 전체 경 주인구 271,869명(경주시, 2012) 대비 소금강 지구 는 $26.9 \%$, 화랑 지구 $12.9 \%$, 서악 지구 $5.4 \%$ 로 나타 났다. 따라서 소금강 지구가 가장 많은 이용인구를 나타낸 것으로 미루어볼 때 이용압력 또한 높다고 할 수 있어 소금강 지구의 탐방로 이용밀도와 그에 따른 훼손도는 비례한다고 생각된다. 대도심 생활권 등산 로가 있는 관악산에서 지속적이고 집중적인 이용특 성에 의해 물리적 환경에 대한 악영향이 발생되며, 대구광역시 내 도심권에 있는 범어공원에서도 이용 자에 따른 훼손이 가장 심하다고 보고하고 있어 도심 내 산지는 과도한 이용인구와 압력에 의해 훼손이 지 속적으로 발생된다(김동욱, 2006; 유기준, 2011). 
즉, 소금강 지구도 다른 지구에 비해 많은 이용인구 가 집중되어 탐방로 훼손이 많음으로 이를 해결하기 위해서는 이용빈도가 집중되는 탐방로는 복원을 위 해 일시 폐쇄하는 것이 필요하며, 이용밀도를 분산하 기 위해 생태적 중요도가 낮은 비법정 탐방로를 개방 하되 이용자수를 지속적으로 파악할 수 있는 게이트 를 설치하는 것이 필요할 것이다.

그리고 소금강 지구 탐방로의 훼손은 주변 생태계 에도 악영향을 미칠 수 있는데 특히 주변 식생에 영 향을 줄 수 있다. 탐방로 주변의 가장자리 식생은 산 림 내부의 식생과 달리 호광성 식물종과 함께 다양한 종구성을 통해 생물서식공간을 형성한다. 특히 가장 자리는 두 개의 상이한 개체군 사이의 전이대로서 하 나의 토지피복이 인접한 토지피복과 상호작용을 하 여 생물적 및 비생물적 변화가 발생되는 중요한 지역 이다(이주미 등, 2012).

즉, 탐방로 주변의 가장자리 식생이 생태적으로 중 요함에도 불구하고 탐방로 상태가 불량하고 이용밀 도가 증가함으로 인해 식생이 영향을 받는다는 것은 국립공원의 생태적 기능이 저하되는 것에 대한 직접 적 요인이 될 수 있다. 따라서 오정학 등(2011)은 토 양유실 방지를 위해 하층식생의 발달을 도모하고 생 태적 천이가 유도될 필요성을 제시하였기에 탐방로 의 나지화 방지를 위해 주변 식생을 보전하는 것이 중요하다. 그리고 자연식생의 훼손과 감소는 주변의 나지화를 유발시켜 토양침식을 더욱 가속화할 수 있 으며, 대체식생으로 귀화식물이 유입될 가능성이 상 당히 높다. 특히 등산로나 탐방로는 산지 내 선적 통 로 역할을 하기 때문에 탐방로 초입에서 발생된 귀화 식물이 내부 깊숙이 침투할 수 있는 매개체가 될 수
있으므로 훼손된 탐방로에 대한 조속한 관리방안이 요구된다.

소금강 지구에서 노면침식, 샛길, 노폭확대, 수목 뿌리 노출이 가장 높게 나타났는데 이들 연관성을 살 펴보면, 이용자가 가장 많음으로 인해 노면의 답압이 많아 토양경도가 높음을 Table 4에서 확인할 수 있 었으며, 특히 경주국립공원 이용행태 조사(경주시, 2005) 시 남산 지구, 토함산 지구, 단석산 지구, 소금 강 지구 중 방문빈도가 가장 높은 지구가 소금강 지 구로 나타났다. 따라서 높은 이용밀도에 따른 토양경 도의 증가는 난투수층을 발생시켜 강우가 토양 내로 침투되지 않고 노면을 유하하기 때문에 각종 충격과 압력으로부터 완충역활을 하는 지피물이 유실됨으로 인해 노면이 강우에 그대로 노출되어 침식이 발생한 다. 따라서 이러한 침식은 노면침식과 함께 주변 수 목의 뿌리를 지상부로 노출시킴으로서 탐방로 상에 수목의 뿌리 노출현상이 심각하게 발생됨과 아울러 이들 뿌리는 탐방로 통행에 방해물로 작용하여 다른 동선을 탐색하기 위해 노폭이 확대됨과 아울러 샛길 발생도 함께 유발시킨다. 즉, 이러한 일련의 훼손유 형의 연관성은 과도한 이용자수와 그에 따른 답압발 생, 이용압력이 주 요인이 되므로 이용자들을 분산할 수 있는 탐방로 관리계획이 수립되어야 할 것이다. 특히 탐방로의 복원을 위한 다양한 공법 시행은 자연 적 복원이 아닌 인위적 복원이기 때문에 이 또한 간 섭이나 교란의 한 요인이 될 수 있으므로 소금강 지 구의 탐방로 복원은 대체 탐방로 선정 및 개방을 통 해 주 탐방로의 이용압력을 최소화하는 것이 가장 좋 은 방법이 될 수 있을 것이다.

Table 6 . The naturalness assessment of trails by districts

\begin{tabular}{|c|c|c|c|c|c|c|c|c|c|c|c|c|c|c|}
\hline \multirow{3}{*}{ District } & \multicolumn{12}{|c|}{ Assessment indicators } & \multicolumn{2}{|c|}{ Total section } \\
\hline & \multicolumn{2}{|c|}{$\begin{array}{l}\text { Trail } \\
\text { erosion }\end{array}$} & \multicolumn{2}{|c|}{$\begin{array}{c}\text { Trail } \\
\text { divergence }\end{array}$} & \multicolumn{2}{|c|}{$\begin{array}{c}\text { Trail } \\
\text { expansion }\end{array}$} & \multicolumn{2}{|c|}{$\begin{array}{c}\text { Rock } \\
\text { exposure }\end{array}$} & \multicolumn{2}{|c|}{$\begin{array}{c}\text { Root } \\
\text { exposure }\end{array}$} & \multicolumn{2}{|c|}{$\begin{array}{l}\text { Deterioration } \\
\text { of surrounding }\end{array}$} & \multirow[t]{2}{*}{ Score } & \multirow[t]{2}{*}{ Degree } \\
\hline & Score & Degree & Score & Degree & Score & Degree & Score & Degree & Score & Degree & Score & Degree & & \\
\hline Sogeumgang & 4.5 & $\mathrm{~V}$ & 3.3 & III & 3.9 & $\mathrm{~V}$ & 3.9 & $\mathrm{~V}$ & 4.3 & $\mathrm{~V}$ & 3.3 & III & 3.9 & $\mathrm{~V}$ \\
\hline Hwarang & 3.8 & $\mathrm{~V}$ & 1.7 & $\mathrm{I}$ & 1.2 & I & 2.1 & II & 3.5 & $\mathrm{~V}$ & 3.1 & III & 2.6 & II \\
\hline Seoak & 3.7 & $\mathrm{~V}$ & 1.0 & I & 3.3 & III & 3.7 & $\mathrm{~V}$ & 1.8 & I & 2.7 & III & 2.7 & III \\
\hline Mean & 4.0 & $\mathrm{~V}$ & 2.0 & II & 2.8 & III & 3.2 & III & 3.2 & III & 3.0 & III & 3.1 & III \\
\hline
\end{tabular}




\section{IV. 결론 및 제언}

본 연구는 경주국립공원에서 도심 내 위치한 소금 강 지구, 화랑 지구, 서악 지구의 탐방로에 대한 물리 적 환경, 훼손 유형 및 자연도를 평가하여 탐방로의 복원 및 관리를 위한 기초 자료 제공에 목적이 있다. 연구결과를 요약하면 다음과 같다.

탐방로 노선길이의 경우 소금강 지구 $0.65 \mathrm{~km}$, 화 랑 지구 $1.3 \mathrm{~km}$, 서악 지구 $1.6 \mathrm{~km}$ 로 선정하였으며, 측점수는 소금강 지구 12 개, 화랑 지구 18 개, 서악 지 구 23 개를 설치하여 조사하였다. 또한 평가지표는 노 면침식, 노폭확대, 수목뿌리노출, 샛길, 암반노출, 노면주변 훼손 등 6 개 지표를 활용하여 최종 자연도 를 평가하였다.

자연도 평가 결과, 소금강 지구는 노면침식 $\mathrm{V}$ 등급, 샛길 III등급, 노폭확대 및 암반노출 V등급, 수목뿌 리노출 V등급, 노면주변훼손 III등급이며, 화랑 지구 는 노면침식 $\mathrm{V}$ 등급, 샛길 및 노폭확대 I등급, 암반노 출 II등급, 수목뿌리노출 V등급, 노면주변훼손 III등 급으로 분석되었다. 서악 지구는 노면침식 $\mathrm{V}$ 등급, 샛 길 I등급, 노폭확대 III등급, 암반노출 $\mathrm{V}$ 등급, 수목뿌 리노출 I등급, 노면주변훼손 III등급으로 확인되었 다. 소금강 지구가 노면침식, 샛길, 노폭확대, 수목 뿌리노출, 암반노출에서 가장 불량한 것으로 분석되 었으며, 지구별 분석의 경우 소금강 지구 $\mathrm{V}$ 등급, 화 랑 지구 II등급, 서악 지구 III등급으로 나타나 소금 강 지구가 가장 불량한 상태였다. 따라서 탐방로 관 리 및 복원대책을 소금강 지구부터 실시해야 할 것으 로 생각되며, 특히 복원공정 시행 전에 이용밀도와 압력을 분산시킬 수 있는 대체 탐방로의 선정과 개방 이 우선적으로 고려되어야 할 것으로 판단된다.

대체적으로 자연도 평가 결과, 노면침식, 수목뿌 리노출, 암반노출이 3 개 지구에서 문제가 있는 것으 로 분석되었다. 따라서 이들에 대한 관리 및 복원방 안을 제안하면 다음과 같다.

첫 번째, 노면침식의 경우 지형복원공법을 적용한 것이 필요하다. 침식지역에 잡석, 왕모래 등을 채워 원지반선과 동일하게 형질을 복원해야 할 것이며, 경 사가 심할 경우 돌계단, 목계단 등을 설치하여 침식
에 의한 토양유실을 최소화해야 할 것이다. 그러나 계단의 답면 높이가 탐방객들에게 불편을 주지 않도 록 최대한 인간척도에 맞게 설계 및 시공을 해야 할 것이며, 특히 돌의 경우 주변에서 채집할 수 있는 자 연석 또는 야면석을 활용하는 것이 주변 경관과 조화 를 이룰 수 있다고 생각된다. 또한 침식은 강우에 의 해 발생되는 경우가 많기 때문에 탐방로 주변에 배수 로 설치하여 인위적, 자연적 침식을 최소화할 수 있 도록 다양한 공종을 적용하는 것이 요구된다.

두 번째, 수목뿌리노출은 노출된 뿌리를 원 상태로 복원하기 위해 수목보호공법을 적용하는 것이 바람 직할 것이다. 특히 노출된 뿌리를 복원하기 위해 공 법을 적용할 시 노출된 뿌리가 최대한 훼손되지 않도 록 하는 것이 필요하다. 또한 토양복토 시 주로 개량 토 등을 사용하나 토양을 외부에서 반입할 시 주변 식생과 다른 종이 발생되어 이질감을 줄 수 있을 뿐 만 아니라 귀화식물이 토양 내 혼입되어 발생될 경우 자연식생의 교란을 야기시킬 수 있으므로 주변의 표 토를 재활용하는 것이 중요하다. 또한 수목의 뿌리는 장기간 노출될 경우 줄기화되는 생리적 특성을 가지 고 있기 때문에 이러한 수목은 복토할 경우 오히려 생육 장애를 발생시킬 수 있으므로 노출된 뿌리 위로 보행을 차단할 수 있는 방지책을 설치하는 것이 훨씬 좋을 것으로 생각된다.

세 번째, 암반노출 지역의 경우 토양을 포설하는 것도 중요하지만 암반 자체가 불투수층이고 토양과 암석의 접한 층이 이질적이기 때문에 근본적인 탐방 로 유지가 어려울 것으로 생각된다. 따라서 이 지역 에는 목재데크, 데크계단 등을 설치하여 탐방로 주변 으로의 동선 확대를 방지해야 할 것이다. 그러나 데 크 설치 구간이 길수록 자연경관과의 부조화가 발생 되고 특히 데크 설치를 위한 기초콘크리트 타설구간 도 함께 증가되기 때문에 자연성을 저하시킬 수 있는 역효과가 발생될 수 있으므로 이들 구간은 최소화할 수 있도록 해야 한다.

본 연구는 경주국립공원에서 이용밀도가 높은 도 심 내 지구들을 대상으로 탐방로를 평가하였기에 향 후 탐방로 복원을 위한 기초 자료로서 활용성이 높을 것으로 기대된다. 그러나 본 연구는 탐방로의 물리적 
특성 및 훼손 유형에 기초하여 평가만을 수행하였기 때문에 전체적인 탐방로의 상태를 파악하는데 한계 가 있다고 판단된다. 따라서 탐방로의 기초 정보를 바탕으로 주변 식생과의 관계, 종조성, 토양성질 등 과 같은 다각적인 관점에서 복합적으로 연구가 진행 되어야 할 것으로 생각된다.

\section{감사의 글}

본 논문은 문성주의 2013년도 동국대학교 대학원 조경학석사학위논문의 일부를 수정 및 보완한 내용이 며, 조사를 허락해주신 국립공원관리공단 자원보전처 및 경주국립공원 사무소 직원분들께 감사드립니다.

\section{참고문헌}

강태호, 유주한, 조홍하, 이홍, 2011, 경주 월성의 산책로 훼손실태 분석-환경피해도 평가를 중심으로-, 한국전통조경학회지, 24(3), 33-39.

경주시, 2005 , 경주국립공원관리계획, 경주시. 경주시, 2012 , 경주시통계연보, 경주시.

국립공원관리공단, 2008 , 경주국립공원 자연자원 조사, 국립공원관리공단.

국립공원관리공단, 2009 , 국립공원 탐방로 정비 매 뉴얼, 국립공원관리공단.

국립공원관리공단, 2011, 2 차 국립공원 훼손지관리 종합계획(안), 국립공원관리공단.

권태호, 1990 , 팔공산 자연공원에서의 등산로 및 야 영장 이용이 자연환경에 미치는 영향, 한국 조경학회지, 17(3), 21-34.

권태호, 김동욱, 이준우, 2005 , 월악산국립공원 등 산로의 훼손실태 분석, 한국환경생태학회 지, 19(2), 130-138.

권태호, 오구균, 권순덕, 1991 , 지리산국립공원의 등산로 및 야영장 주변 환경훼손에 대한 이 용영향, 응용생태연구, 5(1), 91-103.

권태호, 오구균, 권영선, 1988 , 치악산국립공원의 등산로 및 야영장 훼손과 주변 토양 및 식생
환경의 변화, 응용생태연구, 2(1), 50-65. 권태호, 오구균, 이준우, 1990 , 속리산국립공원의 등산로 훼손과 주연부식생에 미치는 영향, 응용생태연구, 4(1), 63-68.

권태호, 오구균, 이준우, 1993 , 소백산국립공원 등 산로의 환경훼손에 대한 이용영향, 응용생 태연구, 6(2), 168-179.

권태호, 오구균, 이준우, 1994, 덕유산국립공원 등 산로 및 야영장의 환경훼손에 대한 이용영 향, 한국환경생태학회지, 7(2), 241-251.

권태호, 오구균, 이준우, 1995 , 주왕산국립공원 등 산로의 이용패턴 및 주변환경 훼손에 대한 이용영향, 응용생태연구 8(2), 167-176.

권태호, 오구균, 이준우, 1996 , 오대산국립공원 이 용에 따른 등산로 및 주변환경훼손, 응용생 태연구, 9(2), 211-220.

권태호, 오구균, 정남훈, 1989 , 가야산국립공원의 등산로 및 야영장 훼손과 주변 환경에 대한 이용영향, 응용생태연구, 3(1), 81-94.

권태호, 이준우, 2003 , 백두대간 마루금 등산로 및 주변 환경의 훼손실태-만복대-복성이재 구 간을 대상으로-, 한국환경생태학회지, 16(4), 465-474.

김동욱, 2006 , 생활권 등산로의 이용자 인식과 정 비방향에 관한 연구-대구광역시를 중심으 로-, 대구대학교 대학원 석사학위논문.

김세천·박종민, 1998 , 모악산도립공원 등산로의 환 경훼손 실태 및 이용 형태에 관한 조사연구, 한국조경학회지, 25(4), 39-50.

김태호, 2003 , 한라산과 다랑쉬오름 등산로의 답압 에 의한 토양 압밀현상, 한국지역지리학회 지, 9(2), 169-179.

김태호, 2011 , 산악 국립공원 등산로의 훼손유형과 요인, 한국지역지리학회지, 17(4), 416-431. 김태호, 2012 , 일본 홋카이도 다이세츠산 국립공원 등산로의 훼손유형 및 요인, 한국지형학회 지, 19(2), 187-195.

문성주, 2013 , 경주국립공원 탐방로의 자연도 평가, 동국대학교 대학원 석사학위논문. 
박은희, 김통일, 정원옥, 권헌교, 정평희, 2010 , 지 리산국립공원 칠선계곡의 탐방로 특성 및 훼 손유형, 한국산림휴양학회지, 14(2), 9-15. 박인환, 이혜영, 조광진, 장갑수, 2010 , 도시자연공 원의 주요 등산로 훼손실태 분석-대구광역 시 앞산공원을 대상으로-, 한국조경학회지, 38(3), 33-40.

박인환, 장갑수, 이근상, 서동조, 2006 , 토양 및 지 형 조건에 따른 토양침식 잠재성 분석-경상 남도 창녕군 이방면을 대상으로-, 환경영향 평가, 15(1), 1-12.

산림청, 2004, 등산로 훼손유형별 생태적 정비요 령: 숲길 정비매뉴얼, 산림청.

서병수, 김세천, 박종민, 이창헌, 이규완, 1994 , 덕 유산국립공원 등산로의 환경훼손에 대한 이 용영향, 한국임학회지, 83(3), 286-298. 안봉원, 권상준, 김용수, 김유일, 이규목, 임승빈, 황 기원, 1991, 조경계획론, 문운당, 128-129. 안현철, 조현서, 추갑철, 1998 , 지리산국립공원의 등 산로 훼손, 농업기술연구소보, 11, 105-111. 오경원, 박종민, $2005, \mathrm{GPS}$ 를 이용한 전주시 덕진 공원 내 숲길 도면작성 및 현황분석, 한국산 림휴양학회지, 9(3), 9-16.

오구균, 권태호, 이준우, 유기준, 최송현, 2005, 숲 길 정비 매뉴얼, 수문출판사, 29-37.

오구균, 권태호, 전용준, 1987 , 북한산국립공원의 등산로 훼손 및 주변 식생변화, 응용생태연 구, 1(1), 35-45.

오구균, 허순호, 1992 , 한라산국립공원의 등산로와 주 변의 환경 훼손, 응용생태연구, 6(1), 55-71. 오정학, 유주한, 김경태, 이우성, 2011, RUSLE 기 법을 이용한 경주지역의 토양침식 위험도 평 가, 환경영향평가, 20(3), 313-324.

유기준, 2011, 관악산 등산로 이용에 따른 영향에 관한 연구, 한국환경생태학회지, 25(1), 111-117.

이주미, 원명수, 임주훈, 이상우, 2012, 가장자리와 산불피해강도가 산불피해지역 초기식생에 미치는 효과, 한국임학회지, 101(1), 121-129.
이준우, 오구균, 권태호, 1997 , 설악산국립공원의 등산로 훼손 및 주연부식생, 한국환경생태 학회지, 10(2), 191-204.

이혜숙, 정길섭, 유환희, 2009, 휴대용 GPS에 의한 등산로 경사분석, 한국지형공간정보학회지, 17(2), 81-90.

임원현, 유주한, 손호기, 김정우, 2009 , 경주 월성 의 생태적 특성 및 진단에 따른 관리방안, 한 국전통조경학회지, 27(3), 39-48.

장은재, 김종원, 2007 , 노거수 생태와 문화, 월드사 이언스, 216-218.

정원옥, 2010 , 탐방로 훼손 특성 및 노면 안정성 평 가, 국립공원연구지, 1(1), 53-58.

정원옥, 강원석, 이봉찬, 2011 , 강천산군립공원 탐 방로의 물리적 특성 및 훼손유형, 국립공원 연구지 2(3), 137-141.

정원옥, 권헌교, 2008 , 소백산국립공원 탐방로의 훼손 특성 및 안정성 평가, 한국산림휴양학 회지, 12(1), 51-57.

정원옥, 정평희, 2010, 한라산국립공원 탐방로의 물 리적 특성 및 훼손유형, 국립공원연구지, 1(4), 255-259.

조우, 2012 , 백두대간권역 국립공원 비개방 탐방로 의 훼손실태, 한국환경생태학회지, 26(5), 827-834.

조현길, 서옥하, 최인화, 안태원, 2011 , 강원도 영서 지역 소나무 마을숲의 생장환경과 관리방 안, 한국환경생태학회지, 25(6), 893-902. 최충호, 박종민, 김선영, 2005 , 전라북도 잔연휴양 림내 숲길 현황 분석, 한국산림휴양학회지, 9(4), 1-14.

Frissell, S.S., 1978, Judging recreation impacts on wildness campsites, Journal of Forestry, 76(8), 481-483.

Leung, Y.F. and J.L. Marion, 1999a, Assessing trail conditions in protected areas: application of a problem-assessment method in Great Smoky Mountains National Park, Environmental 
Conservation, 26(4), 270-279.

Leung, Y.F. and J.L. Marion, 1999b, The influence of sampling interval on the accuracy of trail impact assessment, Landscape and Urban Planning, 43, 167179.

Lynn, N.A. and R.D. Brown, 2003, Effects of recreational use impacts on hiking experiences in natural areas, Landscape and Urban Planning, 64, 77-87.
Moore, R.L., Y.F. Leung, C. Matisoff, C. Dorwart and A. Parker, 2012, Understanding user' perceptions of trail resource impacts and how they affect experiences: an integrated approach, Landscape and Urban Planning, 107, 343-350.

최종원고채택 13. 07. 30 


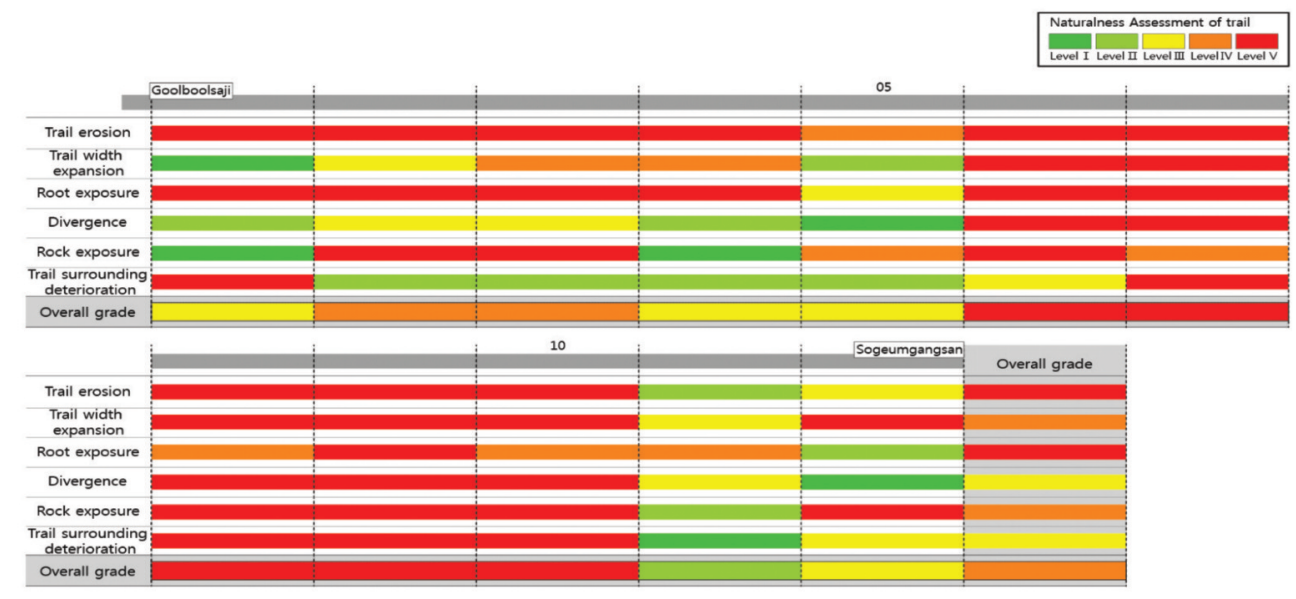

Sogeumgang district

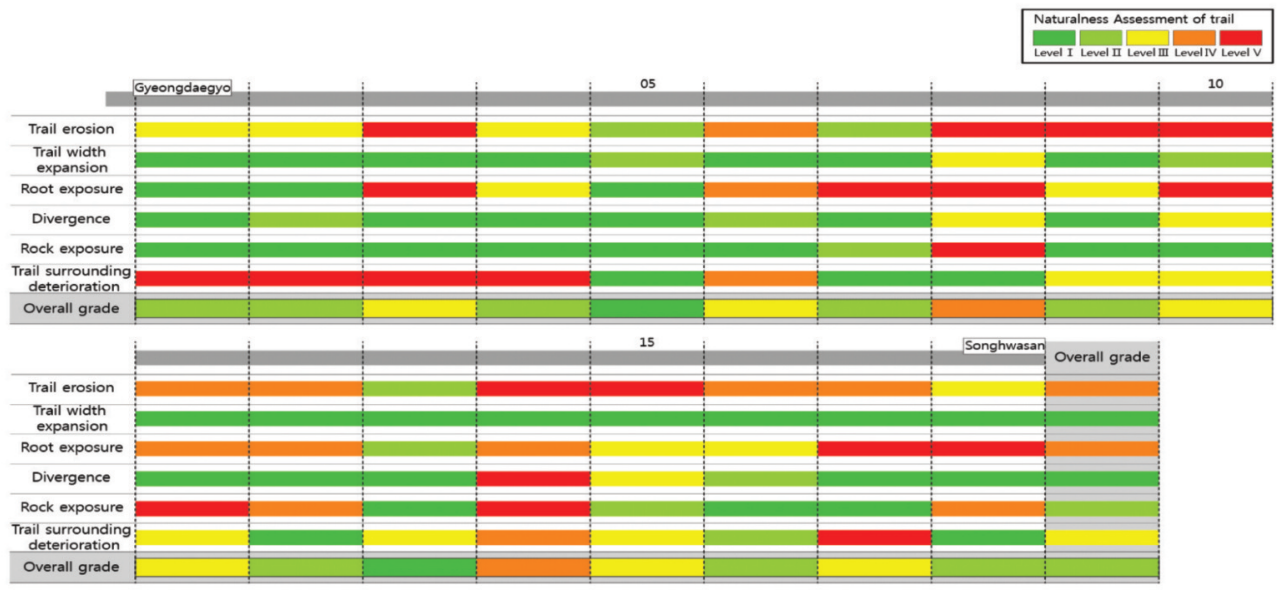

Hwarang district

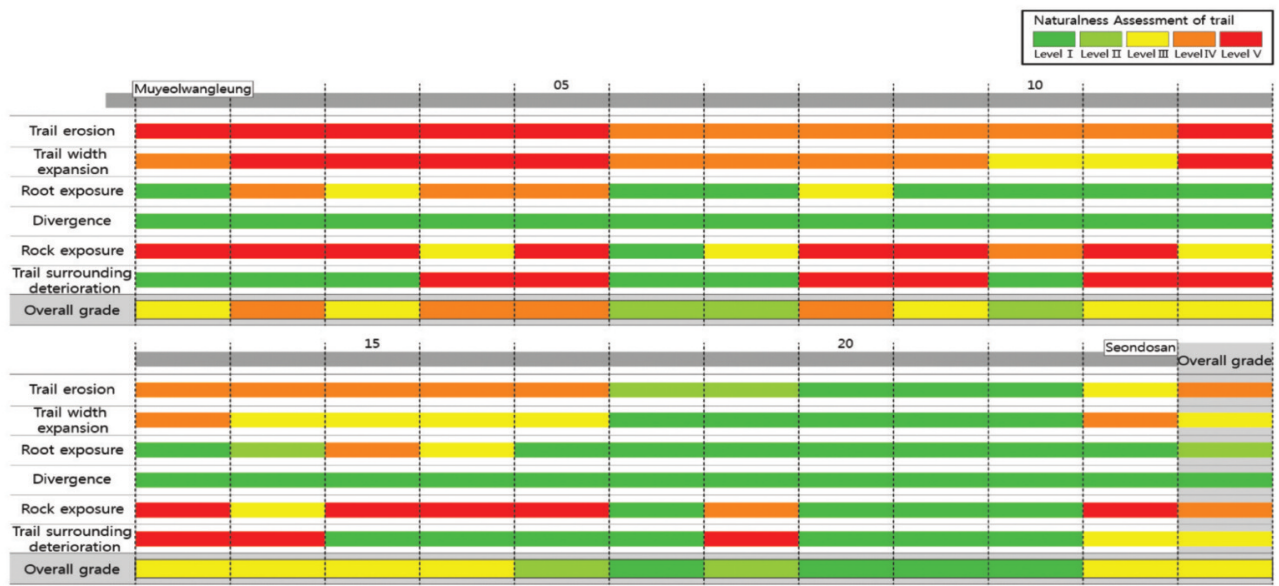

Seoak district

Appendix 1. The naturalness assessment of trails by districts 